\title{
The relations concept of Indonesia-India; political, education, and defense perspective
}

\author{
Adi Bandono*, Avando Bastari and Okol Sri Suharyo \\ Indonesia Naval Technology College, STTAL Surabaya Indonesia.
}

Global Journal of Engineering and Technology Advances, 2021, 07(03), 071-082

Publication history: Received on 04 May 2021; revised on 08 June 2021; accepted on 10 June 2021

Article DOI: https://doi.org/10.30574/gjeta.2021.7.3.0080

\begin{abstract}
Indonesia and India see the Indian Ocean as their strategic political, education, defense, and maritime security. Diplomatic relations between Indonesia and India have been established since 1951 and were upgraded to become a Strategic Partnership in the fields of politics, defense, and maritime security aimed at increasing Confidence Building Measures (CBM). This study aims to analyze the perspective of Indonesia's cooperation with India in the fields of politics, defense and maritime security. The development of Indonesia-India relations has included mutual influence between soft power and hard power. Soft power in Indonesian and Indian foreign policy began to shift to strategic thinking or hard power in entering the stages of the development of Indonesian and Indian Education. This development is in line with Indonesia's foreign policy, which embraces free and active politics. Free means not being bound by ideology or by a foreign country's politics or by a specific bloc of nations, or superpowers, while active means a realistic contribution to developing freedom of friendship and international cooperation by respecting the sovereignty of other countries. Commemorating 70 years of Indonesia-India relations is expected to be a momentum to strengthen strategic cooperation between the two countries is neighboring and have the same interests, covering the Indian Ocean, South China Sea, and the Indo-Pacific as part of emerging strategic entities.
\end{abstract}

Keywords: Indonesia-India; Political; Defense and Security; Education

\section{Introduction}

The history of the closeness of Indonesia-India relations began with the strong support of India in the early days of Indonesian independence, continued with the holding of the Asian-African Conference (AAC) in Bandung in 1955. The closeness of the two countries became stronger when Indonesian President Soekarno and Indian Prime Minister Jawaharlal Nehru together with President Egypt Gamal Abdul Nasser, Yugoslav President Joseph Broz Tito, and Ghanaian President Kwame Nkrumah initiated the establishment of the Non-Aligned Movement in the early 1960 (September, $1^{\text {st }} 1962$ ). They spearheaded the political action of independent countries facing the situation of the cold war between the Western and Eastern blocs. The five heads of state got the nickname The Initiative Five [7]. Jawaharlal Nehru and Soekarno placed and put forward the concerns and interests of non-aligned countries in international forums. The development of historical and cultural relations between the two countries not only prioritizes bilateral relations but also at regional and international levels. Throughout the relationship, the challenge facing the two countries is the trust to continue cooperation in various sectors without the political interests of each country.

Indonesia and India also jointly limited the influence of the superintendency in the Indian Ocean and Southeast Asia through the Indian Ocean Zone of Peace (IOZOP) initiative in the late 1960. IOZOP limits the presence of the navy, especially the United States, Russia (Soviet Union), and China. In the late 1970s, Indonesia withdrew its support for

\footnotetext{
* Corresponding author: Adi Bandono

Indonesia Naval Technology College, STTAL Indonesia.
} 
IOZOP and other proposals that excluded the United States from the region. However, Indonesia and India still must maintain a balance of maritime resilience in the Indian Ocean and Southeast Asia [5].

The geostrategic and geopolitical position of the two countries provide opportunities to become a global economic pathway and an international sea security pathway in the Indian Ocean that places Indonesia-India as having superiority and high dependency in the region. For Indonesia, the maritime and maritime economy has become a top priority in the national economic development plan. Since launching the idea of the World Maritime Axis at the East Asia Summit on November 13, 2014, in Nay Pyi Taw, Myanmar, President Joko Widodo has implemented the doctrine in the form of maritime culture development, maritime economy, maritime infrastructure and connectivity, maritime Education and maritime defense as a form of affirmation that Indonesia has opened up opportunities to develop regional and international cooperation for the prosperity of the people [1], and has a role in determining the period front of the Pacific Ocean and the Indian Ocean regions.

The role of the two countries, Indonesia and India, was continued by becoming a pioneer in cooperation with Indian Ocean Rim Association (IORA) countries. IORA is important for Indonesia, which positions Indonesian waters as a sea lane for world trade traffic that connects the Indian Ocean and the Pacific Ocean and is in line with the vision of the World Maritime Axis [8]. Likewise, India is implementing an increase in maritime policy from Look East Policy to Act East Policy in the Indian Ocean region. IORA is an opportunity for Indonesia and India to show their central role to balance the major power in the region. The World Maritime Axis Policy and the East Policy Act, which were both launched in 2014, place the Indian Ocean as a top priority and make the region safe, peaceful and stable; enhance security cooperation between their partners in the region; strengthen regional mechanisms to secure the oceans; developing a sustainable economy in the region, and opening up to cooperation with external forces in the Indian Ocean.

\section{Materials Review}

\subsection{Academic Education Perspective}

In general, Education is the management of relations between countries carried out to achieve national interests as the implementation of a country's foreign policy [20]. The concept of Education then experienced expansion, both in terms of issues and actors, which gave birth to various forms and types of Education, one of which was maritime Education (maritime Education). In line with the vision of the World Maritime Axis, the reorientation of Indonesia's foreign policy was carried out in a systematic effort to prioritize maritime Education aspects to obtain maximum benefits through bilateral and multilateral cooperation with other countries [9]. Through maritime Education, foreign policy needs to be dedicated and aimed at achieving national interests by observing the identity of a free and active foreign policy, the principle of independence, development-oriented, and prioritizing a rule-based approach.

Maritime Education is the management of international relations through the maritime domain, in the sense of using marine assets owned to manage international relations [12]. Maritime Education no longer only manages conflicts and tensions between countries through the preparation of international legal instruments but also means the use of assets or resources in the maritime domain to regulate relations between countries [12]. If Education generally involves diplomats as state representatives (policymakers), maritime Education can involve analysts and academics to examine trends and developments in international relations and global security. The form of maritime Education in Indonesia is to integrate the ways of soft maritime Education (coordinative and persuasive) and hard maritime Education (coercive). Hard maritime Education is an affirmation of state independence to safeguard its maritime sovereignty from all forms of threats, while soft maritime Education is an active effort to encourage synergistic collaboration [2] and collaboration with various actors.

Education is the implementation of international relations theory which studies the causes and conditions that create cooperation. Collaboration can be created by adjusting the behavior of actors in responding to or anticipating choices made by other actors. Cooperation is a series of relationships that are not based on violence or coercion and legalized. State actors establish cooperative relations through an international organization based on a set of agreed rules, regulations, norms, and decision-making procedures, as expected by the actors and interests of countries that meet in the scope of international relations [6]. Collaboration can grow from an individual's commitment to shared prosperity or as an effort to fulfill personal interests. The key to cooperative behavior lies in the extent to which each individual or state believes that the others will work together in the framework of fulfilling national interests that benefit both parties. The basic idea of security cooperation is that countries work together to maintain security and ensure their national interests. John Gerard Rugie argues that the agreement of cooperation depends on several principles which then underlie the relationship which specifically depends on certain factors [17]. 
Analyzing regional security cannot be separated from the analysis of the emergence of regionalism and the aspects that support it. The theories of regionalism explain historically, why a region can continue to exist and the possibility of efforts made to perpetuate the region. Region or region is defined as a group of countries that have geographical proximity because it is in one particular region [19]. However, geographical proximity alone is not enough to unite the countries in one region. Björn Hettne and Fredrik Söderbaun suggest that such geographical proximity needs to be supported by (a) cultural similarity, (b) social attachment, and (c) shared history [11]. Indonesia and India fully meet these three conditions and are an example to re-pioneer so that all regions in the world can become a group of countries that declare themselves as the same region, namely regions that have the same intensity of interaction and progress between one region and another.

Based on the "New Regional Theory" [10], the development of regionalism depends on three things, namely (a) the support of large forces within the region (regional great power); (b) level of interaction between countries within the region; and (c) mutual trust between countries in the region. India, on the one hand with the support of the United States, Japan and Australia, and Indonesia, on the other hand with the support of ASEAN, can unite to make the Indian Ocean region superior to other regions because it already has a good and strong interaction relationship. Both countries have the capability and capacity to lead to the integration and mutual trust between countries in the region as demonstrated in the Non-aligned Movement and IORA to face some responses from several parties that oppose regionalism, especially the realist, neo-liberal, institutionalist, and constructivist parties as parties who have a different understanding of the influence of regional security in creating conditions conducive to regional security.

\subsection{The Dynamics Strategic Situation in The Indian Ocean}

In the current era, global and regional competition occurs in the Indian Ocean region [3]. Several countries have sought to have a significant influence on the fulfillment of interests in the region, including the interests of Indonesia, India, and several countries in the Indian Ocean region and the presence of extra-regional countries, such as the United States, China, and the European Union.

\subsubsection{Indonesia Interests}

Indonesia has many interests in the Indian Ocean. Since the past, the Indian Ocean has been used as a maritime axis 'The Archipelago Spice Route' that connects India, the Middle East, and China, using shipping modes as part of the Indian Ocean maritime system that stretches from Southeast Asia to Africa. The strategic value of the Indian Ocean is Indonesia's opportunity to meet national interests and strategic objectives in the political and security, economic, sociocultural, and environmental fields.

In the political field, Indonesia has a very strategic position which is in the Indian Ocean region which allows interacting with countries in the region, namely countries in South Asia, the Middle East, and East Africa and regions, such as the United States, China, and Australia. As a large country with military power and a large population, Indonesia should be actively involved in the Indian Ocean region [21].

In the economic field, national interests can be realized through the large opportunities for cooperation in trade and investment through IORA including management of marine resources, development of human resources, economy, and infrastructure, as well as management of sea space and protection of the marine environment [13]. The World Maritime Axis Vision is also an open vision that provides opportunities for international development cooperation, such as investments to build maritime and defense infrastructure.

In the socio-cultural field, Indonesia has a long history of ties with the Indian Ocean and the countries within it that can be seen from various historical facts of the influence of social and cultural life in Indonesia [22]. Archipelago kingdoms that once ruled and sailed in the Indian Ocean certainly is a fact that Indonesia is very close to the Indian Ocean in terms of social and cultural aspects as well as Indonesia's central role in the Bandung KAA 1955. Indonesia's historic role in bridging the interests of Asian-African countries and facilitating strategic alliances between countries in the region are often expressed in international forums, including the Non-aligned Movement, ASEAN, and IORA.

Whereas in the environmental field, Indonesia has an interest in maintaining the sustainability of biodiversity as a potential wealth of large marine resources in the Indian Ocean from the threat of environmental pollution problems originating from ship waste and marine exploitation. 


\subsubsection{India Interests}

India's vision in the Indian Ocean region is reflected in Security and Growth for All in the Region (SAGAR) [18], which means ocean or ocean, which focuses on security and growth in the region. One implementation of this policy is the formation of several maritime infrastructure development projects. This project is called the Sagarmala Project. The project has spent around 70,000 Indian rupees on infrastructure projects and more than 1 trillion Indian rupees for upgrading 12 major ports in India. To realize its policies, India has built a climate of trust and good cooperative relations with its neighbors. This interest can be achieved through investment and assistance in maritime infrastructure development in the Indian Ocean region (IORA), especially in countries such as Bangladesh, Myanmar, Sri Lanka, Maldives, Oman, and Iran. The SAGAR project is an important project for India, where the Indian development project is very significant as a new force in the Indian Ocean region, in the bilateral context between India and Indonesia there is defense cooperation between Indonesia and India which has been implemented since 2002 and has implemented India and Indonesia Coordinated Patrol (CORPAT).

Prime Minister Narendra Modi's great victory in the May 2014 elections provided an opportunity to build this momentum to carve out a greater strategic role for India in the Asia-Pacific. China's increasingly widespread presence in the Indian Ocean and assertiveness in maritime disputes in East Asia have strengthened the relevance of India's enhanced role in East and Southeast Asia for India and its partners in Asia-Pacific. Modi has shown his intention to change the Look East Policy to 'Act East Policy'. Although the Modi Government has stated its intention to focus initially on India's relations with South Asian neighbors, its commitment to pursue economic growth and a more ambitious foreign policy will lead to increased focus towards the east [17]. Initial interactions with East and Southeast Asia were positive, and partnerships with Japan, Vietnam, Australia, ASEAN, and Indonesia had special promises. If the regional situation in South Asia remains stable, it can be expected that India is pursuing a greater role in East and Southeast Asia in line with its growing economic and strategic interests.

\subsubsection{The Interests of Major Power}

An important significant phenomenon affecting the global power competition scheme is Donald Trump's victory in the United States Presidential Election on November 8, 2016. This victory has directly impacted the dynamics of international relations on all fronts and Trump's travel path is following the great tide of conservative group victory in almost all parts of the world, such as the emergence of controversial policies of Gulf countries (Saudi Arabia, United Arab Emirates, Bahrain, Egypt, and Yemen) which severed diplomatic relations simultaneously against Qatar on June 5, 2017, showing the escalation of security in the Gulf region will not subside for some time forward. This condition also triggers tension in the stability of the Indian Ocean region. Likewise, the presence of China experienced significant economic growth. China revived the ancient Silk Road through two main axes, namely the Silk Road Economic Belt or the Silk Road Economic Belt and the 21st Century Maritime Silk Road that gave birth to the Belt and Road Initiative (BRI) as foreign policy and China's economic strategy which gives a lot of access to trade in several countries in the Indian Ocean region [4].

Australia has a strong interest in the IORA because the future of the Australian economy and security around Western Australia will depend heavily on economic stability and security in the Indian Ocean. Australia's view of IORA is considered positive because IORA has a strategic role as one of the forums driving regional stability and IORA can also be directed as the future of the world economy.

Australia is very supportive if the IORA can implement practical engagement that is technical, practical, and effective and target-oriented. Australia has conducted a pilot project in cooperation with SAR and oil spill management techniques in the context of disaster management. The complexity of the latest global issues is a common challenge that affects the way of addressing the two main issues of the IORA above [14]. It can be exemplified that with the rise of popup issues, such as action, terrorism, radicalism, human trafficking, money laundering, drug trafficking, small arms trading, or other transnational crimes are common threats that encourage IORA to immediately take responsive and anticipatory steps to secure a cooperation program.

\section{Results and discussion}

\subsection{The Relations Concept of Indonesia and India in the Years 2020-2025}

Indonesia and India are two democracies that play a very important role in the international world. Both countries also have very diverse populations in terms of culture, language, religion, and ethnicity. Relations between the two countries have even existed since time immemorial before Indonesia's independence, even since the Srivijaya era in the $7^{\text {th }}$ century. The relations between the two countries were strengthened because of the similarities in history, culture, 
customs, beliefs, and economics that colored the long relationship between Indonesia and India. Based on the theory of regionalism, the two countries together need to develop a concept of relations in strengthening better bilateral relations in politics, defense and security, see Figure 1.

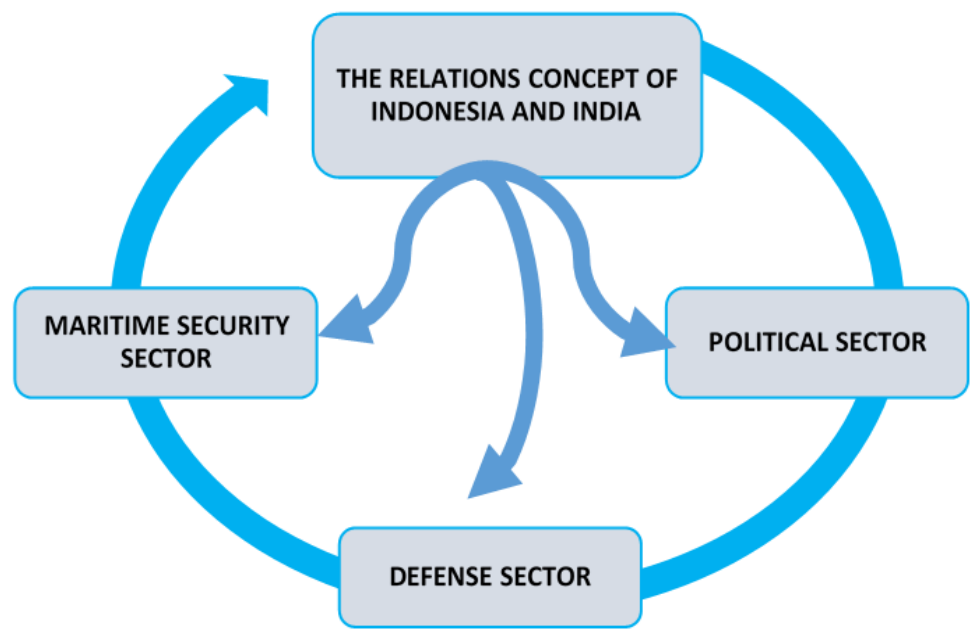

Figure 1 The Relation Concept of Indonesia and India

Based on the theory of regionalism, the two countries together need to develop a concept of relations in strengthening better bilateral relations in politics, defense and security to strengthen investment and trade, maintain the sustainability of marine resources, and improve maritime security in the region by promoting cooperation maritime, connectivity, and sustainable development and not prioritizing competition so that the two countries can continue to contribute to world peace, stability, and prosperity.

\subsection{Political Sector}

In the field of politics and foreign policy, Indonesia and India can again spearhead the rise of countries in the region through IORA, the Non-Aligned Movement, and India-ASEAN relations. IORA is an association of Indian Ocean circumference became one of the tangible forms of the implementation of Indonesian and Indian maritime Education with countries in the Indian Ocean Region and the region. Through IORA, modern and innovative maritime Education requires the ability to accommodate a wider range of issues and more diverse actors to develop creative strategies in dealing with the complexities of relations between countries. Bilateral relations between Indonesia and India must be strengthened and become a power base in the region and strengthen interregional and global relations and make IORA a forum to build a regional identity in the arena of international Education.

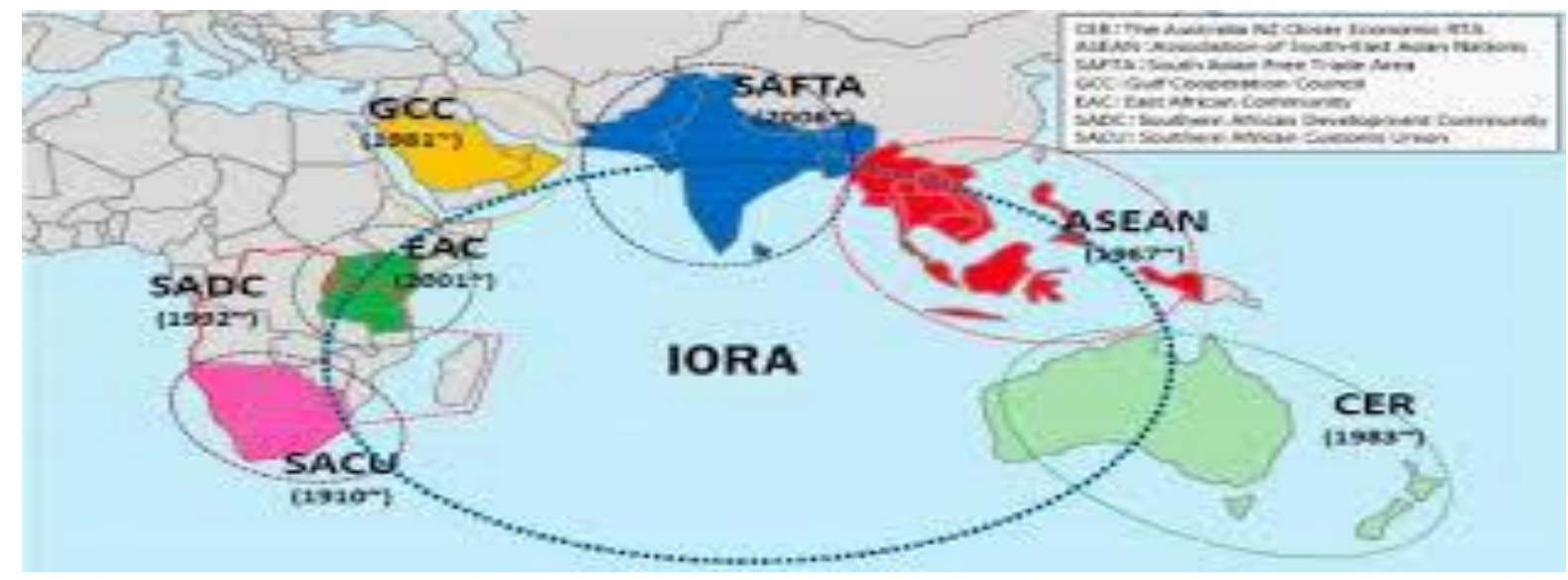

Figure 1 IORA among other Multilateral Cooperation

Indonesia and India remain the foundation of the Non-Aligned Movement to carry out five basic principles, namely respecting territorial integration, non-aggression agreements, not intervening in domestic affairs, equality, and maintaining peace to peacefully resolve conflicts, disarm nuclear weapons, build the closeness of relations between 
civilizations, and a new world order based on the balance in the interests and demands of humanity [23]. The NonAligned Movement must prove its capacity to solve various problems, such as those in the Middle East, tensions on the Korean peninsula, and humanitarian issues in Palestine and Myanmar, etc., as a form of active contribution to the struggle for independence, peace, and social justice.

Through Indonesia, India can strengthen relations with ASEAN countries and expand its influence in the Southeast Asian region by reorienting its foreign policy priorities. India initiated the East Policy Act and re-established economic relations with Southeast Asia [25]. With the increasing economic growth of Indonesia and India as an influential country in the Indian Ocean region, Indonesia can support India in implementing the East Policy Act policy to form closer economic and strategic relations with ASEAN. This success is considered as recognition of India's emergence as a key player in the Asia Pacific region. Through India-ASEAN relations, economic relations become broad and strong which are realized in the fields of trade in goods, services, and investment to be able to increase the competitiveness of the two countries as producers, exporters, and service providers in the global market. To further strengthen relations between the two countries, Indonesia and India need to strengthen Jakarta-New Delhi relations in the form of a Joint Working Group, exchange of parliamentary visits, and exchange of cultural visits that are more intensive and institutionalized. As a large country in terms of area and population and abundant natural resources, the Jakarta-New Delhi relationship is a media to continue to take advantage of economic opportunities, political power, and cooperation to deal with the hegemony of the superintendent state in the Indian Ocean.

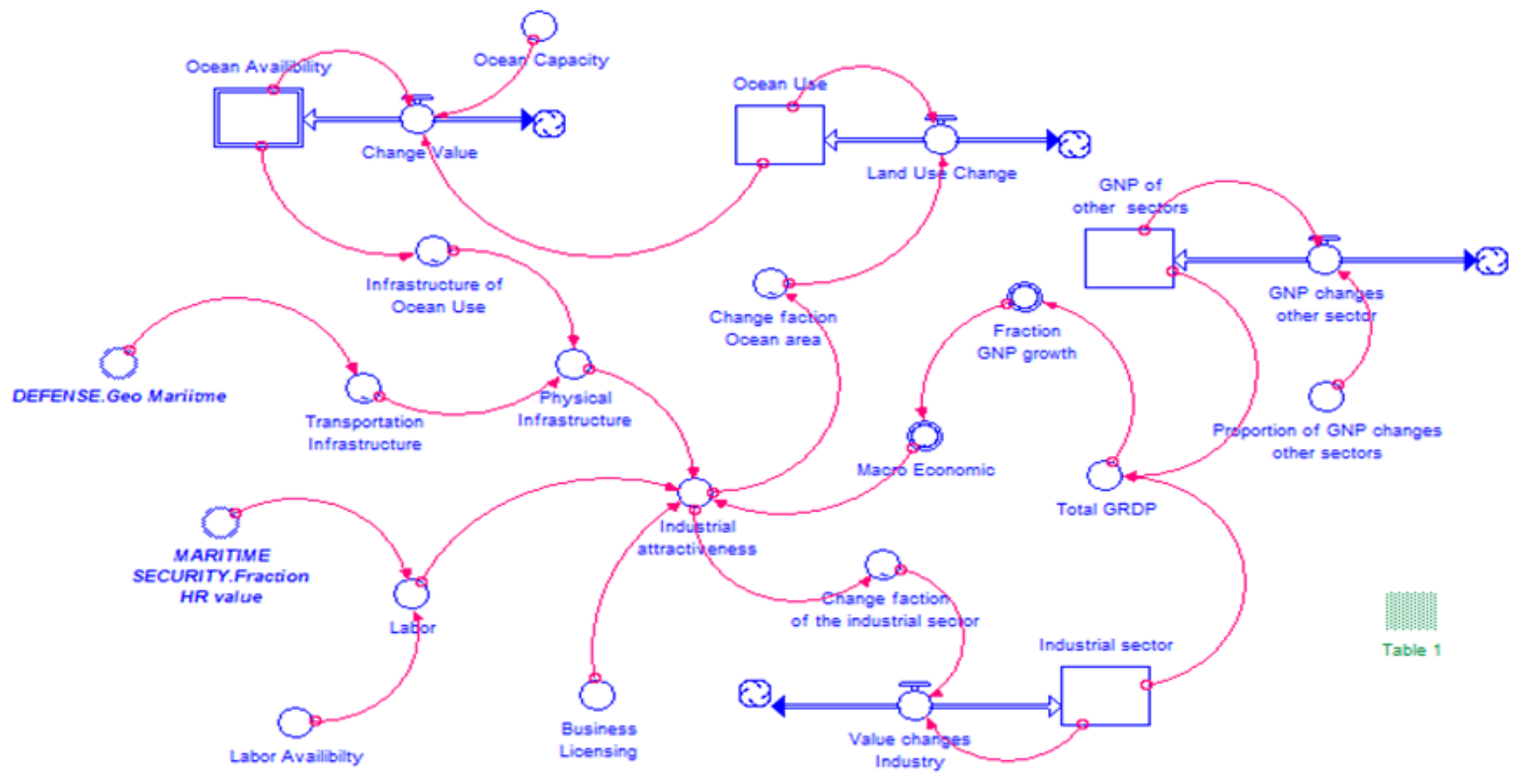

Figure 2 Interaction of Political Sector- Indonesia India Relations

\subsubsection{Formulation model of political sector interaction}

\section{POLITICAL:}

GNP_of_other_sectors $(\mathrm{t})=\mathrm{GNP}$ _of_other_sectors $(\mathrm{t}-\mathrm{dt})+(\mathrm{GNP}$ _changes_other_sector $) * \mathrm{dt}$

INIT GNP_of_other_sectors = 548235203.21

INFLOWS:

GNP_changes_other_sector $=$ GNP_of_other_sectors*Proportion_of_GNP_changes_other_sectors

Industrial_sector $(\mathrm{t})=$ Industrial_sector $(\mathrm{t}-\mathrm{dt})+($ Value_changes_Industry $) * \mathrm{dt}$

INIT Industrial_sector $=520457423.42$

INFLOWS:

Value_changes_Industry $=$ (Industrial_sector*Change_faction_of_the_industrial_sector)

Ocean_Availibility $(\mathrm{t})=$ Ocean_Availibility $(\mathrm{t}-\mathrm{dt})+($ Change_Value $){ }^{*} \mathrm{dt}$

INIT Ocean_Availibility $=5$

INFLOWS:

Change_Value $=($ Ocean_Capacity $/$ Ocean_Use $)-O c e a n \_A v a i l i b i l i t y$

Ocean_Use $(\mathrm{t})=$ Ocean_Use $(\mathrm{t}-\mathrm{dt})+($ Land_Use_Change $) * d t$

INIT Ocean_Use $=6$ 


\subsection{Defense Sector}

At present, Indonesia and India already have three bilateral cooperation forums on defense and security, namely the Biennial Meeting at the Minister of Defense level; Indonesia-India Security Dialogue (IISD); and the Joint Defense Cooperation Committee (JDCC) at the level of the Secretary-General of the Ministry of Defense. Therefore, cooperation in the field of defense can be increased at the operational level by establishing a Bilateral Defense Forum (IndonesiaIndia Bilateral Defense Forum). The points of cooperation include education, training, and military research, as well as operational counter terrorism and humanitarian assistance, and natural disaster [15].

In the field of maritime security operations in the Indian Ocean region and the Bay of Bengal and the borders of the two countries, Indonesia and India can improve relations by building the Port Blair (Nicobar-Andaman) -Sabang (Aceh) route by increasing the intensity of patrols from coordinated patrol to coordinated patrol to Joint Patrol was followed by an exchange of liaison officers between Naval base Port Blair and Naval Base Sabang. the Port Blair-Sabang route allows the Navy of the two countries to utilize base facilities (sea and air) [24]. Both countries have great naval power and the ability to deal with various criminal offenses at sea in the region.

The concept of defense cooperation between Indonesia and India above can be strengthened in a better direction by increasing naval cooperation between the two countries such as information exchange, as fellow maritime nations. Exchange of information at the operational level of the two navies (Indian Navy and Indonesia Navy) in the field of

security and safety, with the format of the White Shipping Agreement, between the Indian Navy's Information Fusion Center (IFC) and the Indonesia Navy's Command and Control Center, including information exchange between Port Blair and Sabang Navy bases. The use of the white shipping format as an information network protocol allows the navies of the two countries to exchange information. Cooperation is also developed in the field of maritime and infrastructure development, especially on Andaman-Nicobar Island, India, and Sabang Island, North Sumatra, such as the establishment of a Maritime Command Center to facilitate coordination and control of joint patrols.

Other defense cooperation is defense industry cooperation. Both countries have defense industries with technological advantages they have. Seven of Indonesia's flagship defense industry programs are (a) The KF X / IF X fighter jet development program; (b) Submarine construction; (c) National radar development; (d) Development of the propellant industry; (e) Developing medium tanks and heavy tanks (playing battle tanks); (f) Missile development; and (g) Development of defense rockets. While India has the advantage of mastering long-range missile technology, aerospace industry, space technology, shipbuilding, and weaponry.

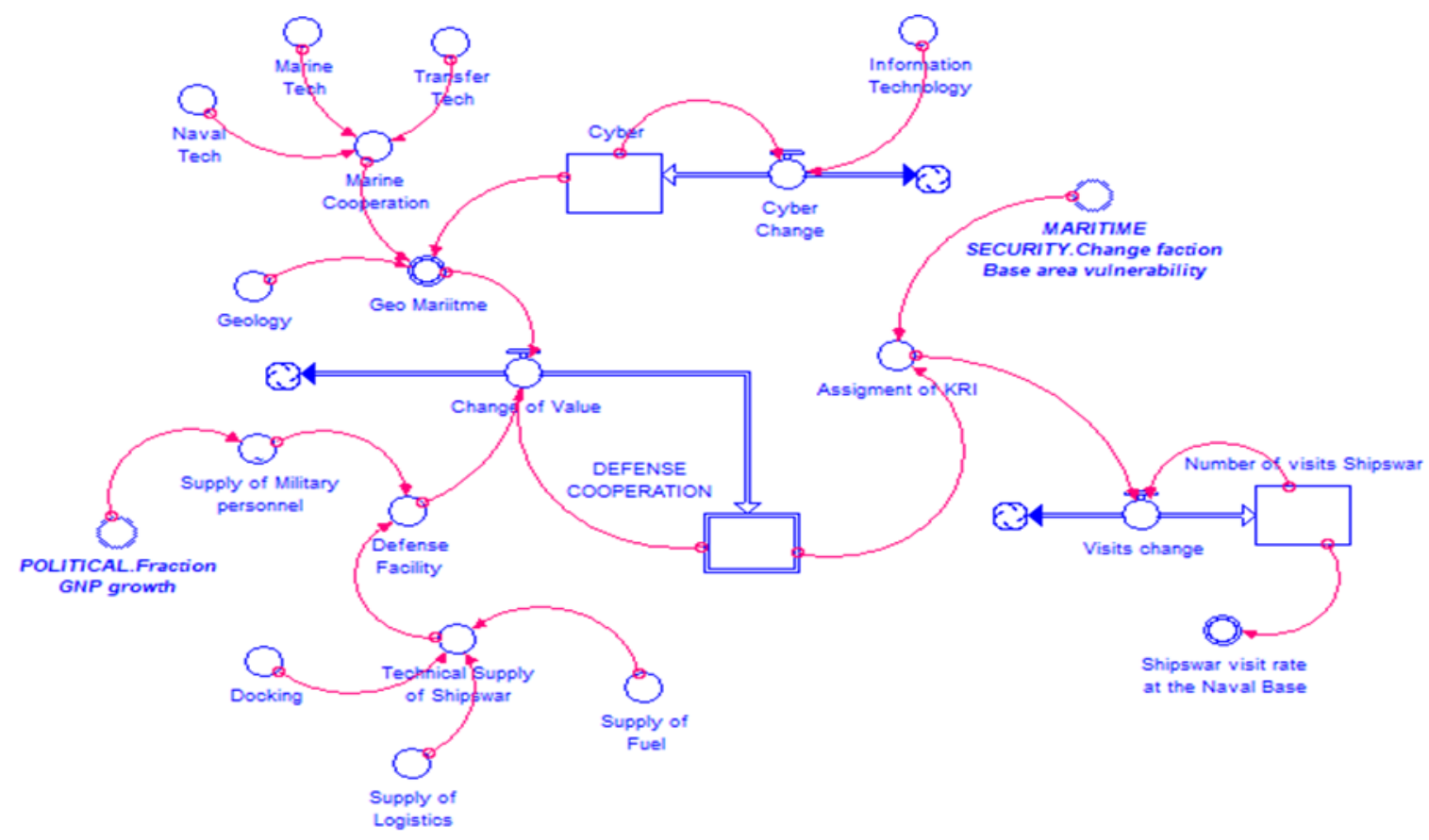

Figure 2 Interaction of Defense Sector- Indonesia India Relations 


\subsubsection{Formulation model of defense sector interaction}

DEFENSE:

Cyber $(\mathrm{t})=$ Cyber $(\mathrm{t}-\mathrm{dt})+($ Cyber_Change $) * d t$

INIT Cyber $=4$

INFLOWS:

Cyber_Change $=$ Cyber*Information_Technology

DEFENSE_COOPERATION $(\mathrm{t})=$ DEFENSE_COOPERATION $(\mathrm{t}-\mathrm{dt})+($ Change_of_Value $) * \mathrm{dt}$

INIT DEFENSE_COOPERATION = 4

INFLOWS:

Change_of_Value $=($ Geo_Maritime+Defense_Facility $) / 2$ - DEFENSE_COOPERATION

Number_of_visits_Shipswar $(\mathrm{t})=$ Number_of_visits_Shipswar $(\mathrm{t}-\mathrm{dt})+($ Visits_change $) * d t$

INIT Number_of_visits_Shipswar $=10$

INFLOWS:

Visits_change $=$ Round ((Number_of_visits_Shipswar*Assigment_of_KRI))

Assigment_of_KRI = (DEFENSE_COOPERATION+MARITIME_SECURITY.Change_faction_Base_area_vulnerability $) / 2$

Defense_Facility $=\left(100^{*}\right.$ Supply_of_Military_personnel+Technical_Supply_of_Shipswar $) / 2$

Docking $=$ random $(6,7,1)$

Geology = random $(5,6,1)$

Geo_Mariitme $=($ Geology+Marine_Cooperation+Cyber $) / 3$

Information_Technology $=0.04$

Marine_Tech $=$ random $(3,4,1)$

Marine_Cooperation $=($ Naval_Tech + Transfer_Tech+Marine_Tech $) / 3$

Naval_Tech $=$ random $(4,5,1)$

Shipswar_visit_rate_at_the_Naval_Base = IF TIME=0 then 0.12 else (Number_of_visits_Shipswar- History

(Number_of_visits_Shipswar, time-1))/Number_of_visits_Shipswar

Supply_of_Fuel = random $(8,9,1)$

Supply_of_Logistics = random $(8,9,1)$

Technical_Supply_of_Shipswar $=($ Docking+Supply_of_Logistics+Supply_of_Fuel $) / 3$

Transfer_Tech $=$ random $(3,4,1)$

Supply_of_Military_personnel = GRAPH (POLITICAL.Fraction_GNP_growth)

$(0.00,0.015),(0.1,0.035),(0.2,0.065),(0.3,0.115),(0.4,0.26),(0.5,0.37)$

\subsection{Maritime Security Sector}

Mutually beneficial cooperation between Indonesia and India is highly prioritized during a dynamic geopolitical situation and the efforts of large countries to compete for influence in the region. Indonesia and India are united by Indian Ocean waters and the waters of the Bay of Bengal as an important part of the future of the Global Maritime Fulcrum Policy and the East Policy Act so that cooperation in the field of maritime security and safety is a priority. Indonesia and ASEAN are developing the ASEAN Indo-Pacific Outlook, welcoming India's commitment to contribute to the development of the Indo-Pacific region's architecture.

Indonesia and India need to form a forum that allows discussion across maritime security institutions, such as the navy and coastguard so that the three can collaborate and carry out their duties in an integrated manner to realize effective and efficient marine safeguards. The existence of MCC, Information Sharing, and Liaison Officer will facilitate implementation with the three forums at the top level (Biennial Meeting, SIID, and JDCC). This collaboration will further facilitate cross-organizational capacity building (navy, coast guard) for better maritime resilience in the Indian Ocean region and the Bay of Bengal in northern Sumatra. Maritime security and maritime cooperation between the navy, coast guard, and various government institutions from the countries of the Indian Ocean region and superintendent countries is very much in line with global interests and the United Nations (UN) program and the Sustainable Development Goals (SDG) [16].

New initiatives in multilateral cooperation in the regional context are needed to maintain maritime security and safety in the waters of Sumatra, the Andaman Sea to the Bay of Bengal involving Sri Lanka, India, Myanmar, Bangladesh, Indonesia and Thailand Bengal-Andaman-Sumatra in the format of SIMBIT-BAS Cooperation (Sri Lanka, India, Myanmar, Bangladesh, Indonesia, and Thailand at Bengal-Andaman-Sumatra Cooperation). Maritime security and safety cooperation in this region aims to be prepared in overcoming the threat of terrorism, disaster management, and SAR. Various opportunities can be explored to expand this cooperation to protect the Indian Ocean marine ecosystems as well as integrated efforts to tackle climate change. 


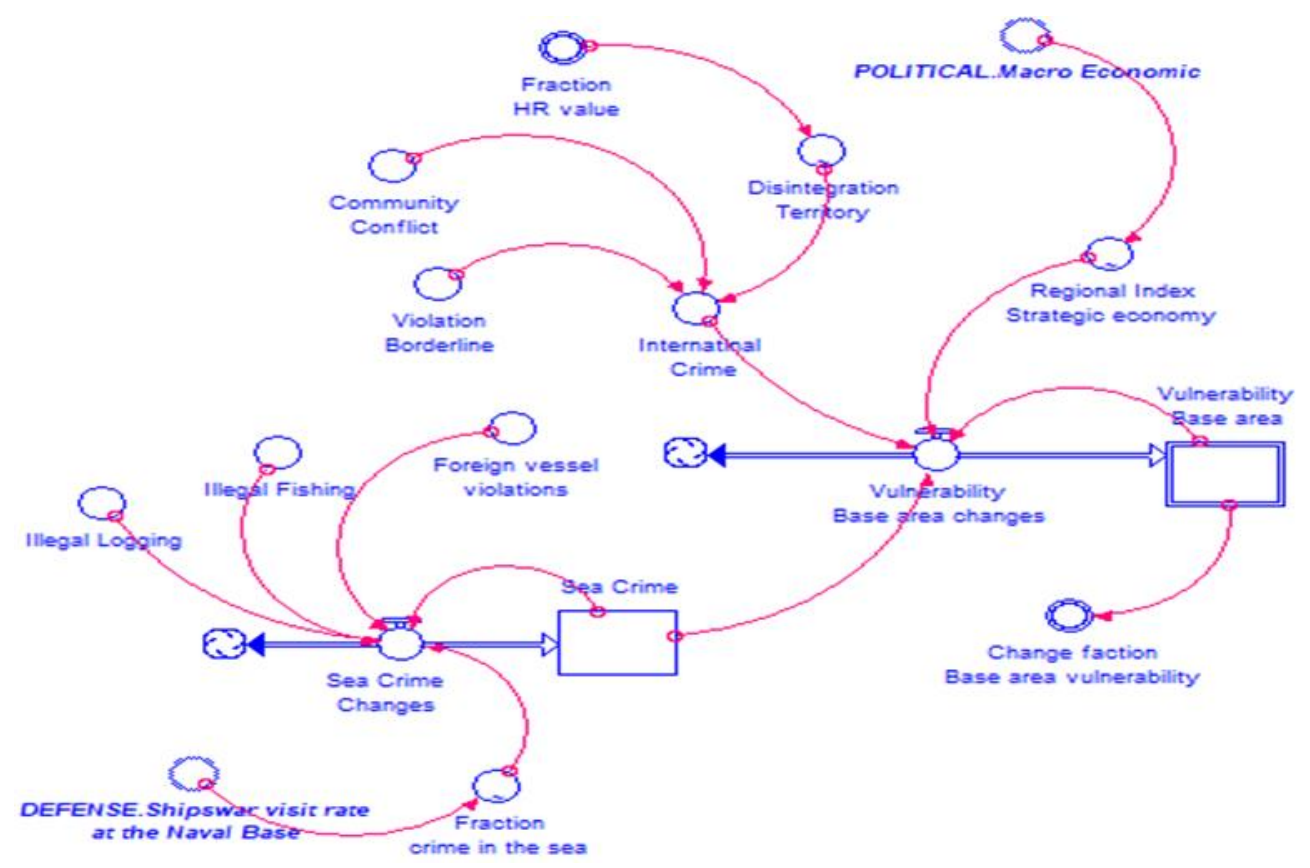

Figure 3 Interaction of Maritime Security Sector- Indonesia India Relations

\subsubsection{Formulation model of maritime security sector interacton}

\section{MARITIME SECURITY:}

Sea_Crime $(\mathrm{t})=$ Sea_Crime $(\mathrm{t}-\mathrm{dt})+($ Sea_Crime_Changes $) * d t$

INIT Sea_Crime $=4$

INFLOWS:

Sea_Crime_Changes

(Sea_Crime+Illegal_Fishing+Illegal_Logging+Foreign_vessel_violations)*Fraction_crime_in_the_sea

Vulnerability_Base_area $(\mathrm{t})=$ Vulnerability_Base_area $(\mathrm{t}-\mathrm{dt})+($ Vulnerability_Base_area_changes $) * \mathrm{dt}$

INIT Vulnerability_Base_area $=3.5$

INFLOWS:

Vulnerability_Base_area_changes = = ((Sea_Crime+Land_Crime+Regional_Index_Strategic_economy)/3)-

Vulnerability_Base_area+1

Change_faction_Base_area_vulnerability $=$ IF TIME $=0$ then 0.12 else (Vulnerability_Base_area- History

(Vulnerability_Base_area, time-1))/Vulnerability_Base_area

Community_Conflict $=$ random $(4,5,1)$

Foreign_vessel_violations $=$ random $(4,5)$

Fraction_HR_value $=0.04$

Illegal_Fishing $=$ random $(4,5,1)$

Illegal_Logging = random $(5,6,1)$

International_Crime $=($ Disintegration_Territory + Community_Conflict+Violation_Borderline $) / 3$

Violation_Borderline $=$ random $(7,8,1)$

Disintegration_Territory $=$ GRAPH (Fraction_HR_value)

(0.00, 0.97), (0.1, 0.75), (0.2, 0.62), (0.3, 0.515), (0.4, 0.43), $(0.5,0.355)$

Fraction_crime_in_the_sea = GRAPH (DEFENSE.Shipswar_visit_rate_at_the_Naval_Base)

$(0.00,0.302),(0.1,0.19),(0.2,0.133)$

\subsection{The Sustainability Model of Indonesia India Relations Concept}

Indonesia India Relations Sustainability is a dynamic condition of cooperation which includes all aspects that are integrated, containing resilience and sustainability which contains the ability to develop the strength of the cooperation in accordance with its function in dealing with and overcoming all challenges, threats, obstacles and disturbances, both coming from outside or from in, which directly or indirectly endangers the integrity, identity and survival of the Indonesia-India Relationships. Figure 4. shows the causal loop diagram integration relationship between all cooperation in the Indonesia-India Relationships. This collaboration can increase the value of Indonesia-India Relationships 
sustainability. The Indonesia India Relationships sustainability value formulation can be defined as a loop relationship model based on the time dimension which can be shown as follows:

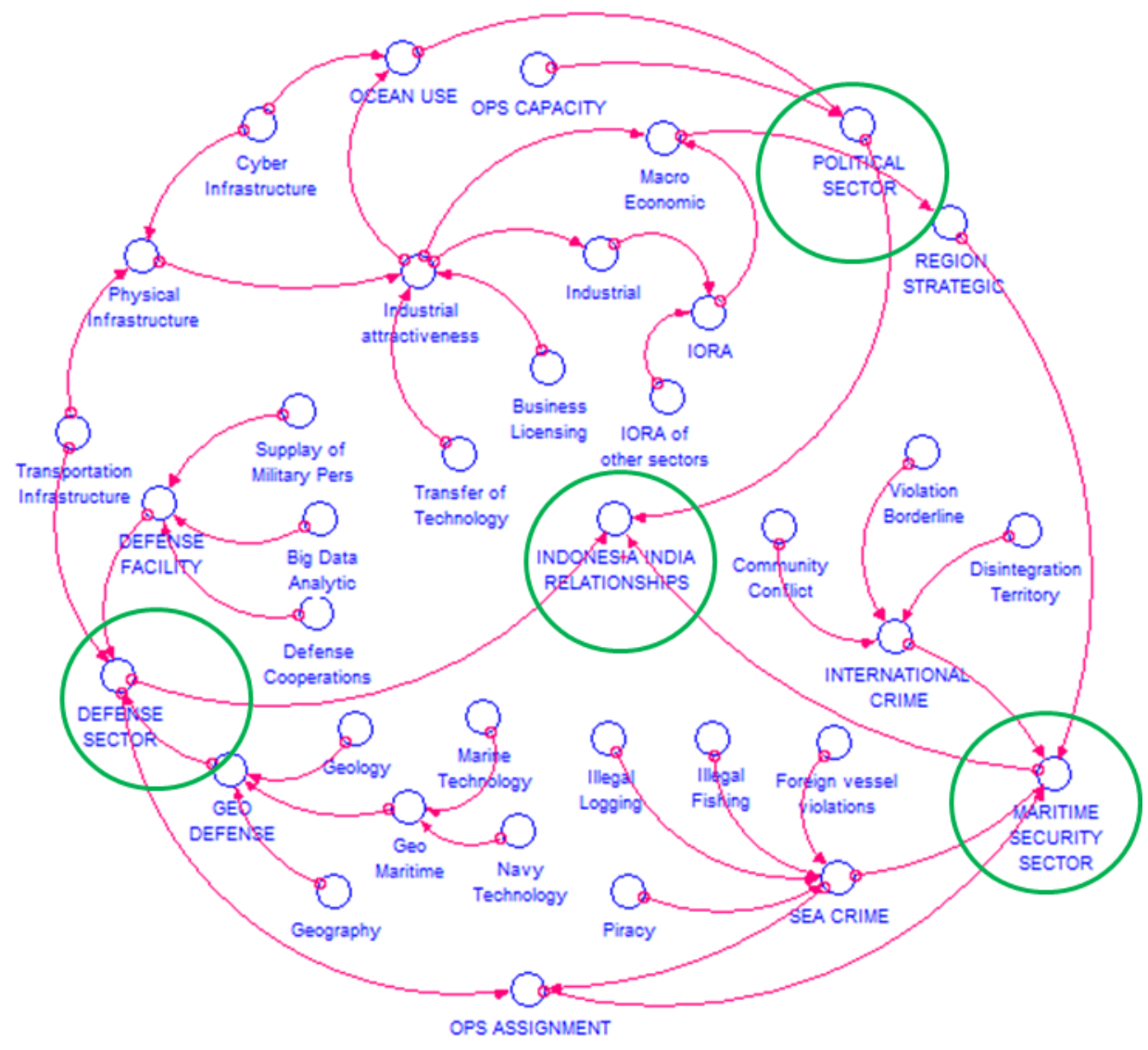

Figure 4 Interaction of variables in the Relationship Model of Indonesia-India

\subsubsection{The formulation sustainability model of indonesia-india relationships:}

INDONESIA INDIA RELATIONSHIPS:

INDONESIA_INDIA_RELATIONSHIPS $(\mathrm{t})=$ INDONESIA_INDIA_RELATIONSHIPS $(\mathrm{t}-\mathrm{dt})+($ Value_Change $) * \mathrm{dt}$ INIT INDONESIA_INDIA_RELATIONSHIPS $=4$

INFLOWS:

Value_Change

((MARITIME_SECURITY.Vulnerability_Base_area+POLITICAL.Ocean_Availibility+DEFENSE.DEFENSE_COOPERATION) /3)-INDONESIA_INDIA_RELATIONSHIPS

\section{Conclusion}

Cooperation between Indonesia and India is emphasized on enhancing and strengthening bilateral relations for regional interests to reach the Indian Ocean and Indo-Pacific regions that are free, open, transparent, rule-based, peaceful, prosperous, and inclusive, a place of sovereignty and territorial integrity, international law, freedom navigation and aviation, sustainable development, and trade, investment system that is open, free, fair and respectful.

The improvement and strengthening are carried out through efforts to bring ASEAN and IORA closer to creating stable stability of the Indian Ocean region and impacting the stability of the Indo-Pacific and global region based on shared views in facing common problems and challenges according to Indonesia's maritime vision policy 'World Maritime Axis' and policies Indian maritime 'East Policy Act'.

Cooperation between Indonesia and India is also emphasized in efforts to empower the potential of natural resources in the Indian Ocean for the common good. For Indonesia, India is a potential partner in playing an important role in the Indian Ocean regional order, especially in establishing security-based partnerships through a gradual process. As for 
India, Indonesia is a very strategic partner in several respects, primarily Indonesia as the largest country in Southeast Asia and considered an equal partner in ASEAN.

Security-based partnerships are realized in the form of guarding marine resources and creating seafood sovereignty; give priority to infrastructure development and maritime connectivity; and maritime Education realized through increased cooperation in handling maritime security in the region, such as IUU Fishing, violations of sovereignty, territorial disputes, piracy, piracy, and sea pollution through joint exercises and/or joint exercises with the Indian and Indonesian Navy conducted in the Malacca Strait to Andaman-Nicobar Islands. The exercises can invite the participation of the Air Force, Police, Coast Guard, and other civil components. Strengthening maritime cooperation as a very strategic partner becomes the basis for building effective and sustainable Indian Ocean maritime resilience. Indonesia and India have the capacity and capability to take on the role of initiators as well as balancing the settlement of interests between nations in the region or between countries with regional powers to maintain security stability in the Indian Ocean region and international stability in general.

\section{Compliance with ethical standards}

\section{Acknowledgments}

The authors greatly acknowledge the support from The Indonesia Naval Technology College STTAL Surabaya Indonesia for providing the necessary resources to carry out this research work. The authors are also grateful to the anonymous reviewers and journal editorial board for their many insightful comments, which have significantly improved this article.

\section{Disclosure of conflict of interest}

The authors declared no potential conflicts of interest with respect to the research, authorship, and/or publication of this article.

\section{References}

[1] Ahmadi, Herdiawan D. The application of CBA and SUG model for improving the quality of Indonesian navy human resources. International Journal of Recent Technology and Engineering. 2019; 8(3): 393-399.

[2] Ahmadi, Sumantri SH, Suharyo OS, Kukuh Susilo A. Selection anti-submarine sensor of helicopter using the Electre III method. International Journal of Applied Engineering Research. 2017; 12 (9): 1974-1981.

[3] Astika IMJ, Sukandari B, Sutrisno, Suharyo OS. Powder smoke composite building design as a weapon of the sea, air, and land defense sabotage. International Journal of Scientific and Technology Research. 2020; 9(1): 17281736.

[4] Bandono ADI, Suharyo OS, Riono. Applied fuzzy and Nasa TLX method to measure of the mental workload. Journal of Theoretical and Applied Information Technology. 2019; 97(2): 476-489.

[5] Brewster, David. The relationship between India and Indonesia: An Evolving Security Partnership?. California: Asian Survey. 2010.

[6] Dougherty James E, Robert L Pfaltzgraff. Contending Theories. New York: Happer and Row Publisher. 1997.

[7] Hatta, Mohammad. Indonesia dan Non-Alignment. Jakarta: Bulan Bintang. 1982.

[8] Herdiawan D, Ahmadi. Development strategy of national food sovereignty to encounter radicalism threat. International Journal of Innovative Technology and Exploring Engineering. 2019; 8(11): 544-553.

[9] Heru Kreshna Reza, Sukmo Hadi Nugroho. (2020). The Assessment of Work Performance, Education, and Self Motivation on Organizational Citizenship Behavior. International Journal of Advanced Science and Technology. $2020 ; 29(3): 8019-8030$.

[10] Hettne, Bjorn. The New Regionalism: A Prologue. In Hettne, B. (ed), The New Regionalism and the Future of Security Development. 2000; 4.

[11] Hettne, Bjorn, Fredrik Soderbaun. Theorizing the Rise of Regions". London: Routledge. 2002.

[12] Miere, Christian Lee. Maritime Education in the 21st Century: Drivers and Challenges. New York: Routledge. 2014. 
[13] Nugroho SH, Madhakomala R, Gunawan K. The system dynamic model for policy evaluation of navy personnel on the state-duty aspect. International Journal of Scientific and Technology Research. 2019; 8(12): 228-236.

[14] Nugroho SH, Sukandari B, Suharyo OS, Bandono A. The application of Nasa-Tlx methods to the analysis of Mtf navy personnel allocation. International Journal of Scientific and Technology Research. 2020; 9(3): 6172-6179.

[15] Nugroho SH, Sukandari B, Bandono A, Sri Suharyo O. The applications of model bayesian networks for analysis and preventive actions on maritime security operations. International Journal of Scientific and Technology Research. 2020; 9(3): 3000-3006.

[16] Octavian, Amarulla. Goa Maritime Symposium: Building stronger Maritime Partnership in Indian Ocean Regional, Naval War College, Goa, India October 16th-18 ${ }^{\text {th }} .2018$.

[17] Ruggie, John Gerard. Multilateralism: The Theory of an Institution, Multilateralism Matters: The Theory and Praxis of an Institutional Norm, ed. John Gerard Ruggie, Columbia, NY: Columbia University Press. 1993.

[18] Singh, Uday Bhanu. Emerging India-Indonesia Comprehensive Strategic Partnership. New Delhi: IDSA. 2018.

[19] Snyder, Craig A. Contemporary Security and Strategy. Palgrave: Macmillan. 2008.

[20] Setiadji A, Marsetio, Ahmadi. The assessment of strategic planning and strategic change management to improve organizational performance. International Journal of Advanced Science and Technology. 2019; 29(5): 682-698.

[21] Suharjo B, Suharyo OS, Bandono A. Failure mode effect and criticality analysis (FMECA) for determination time interval replacement of critical components in warships radar. Journal of Theoretical and Applied Information Technology. 2019; 97(10): 2861-2870.

[22] Suharjo B. Using System Dynamics to Analyze the Leadership Style on Motivation and Soldier's Performance. In E3S Web of Conferences. 2019; 125.

[23] Sumantri SH, Bastari A, Sri Suharyo 0. The assessment of naval base sustainability using a dynamic system thinking approach. International Journal of Scientific and Technology Research. 2019; 8(11): 388-394.

[24] Susilo AK, Putra IN, Ahmadi, Suharyo OS. Analysis of national maritime security strategy as an effect of regional development using SWOT, fuzzy multi-criteria decision making (FMCDM), and borda. International Journal of Operations and Quantitative Management. 2020; 25(3): 153-174.

[25] Zhao Hong. India's Changing Relations with ASEAN: From China's Perspective. East Asian Institute Working. 2006; 133. 